Article

\title{
Overcoming Drag at the Water-Air Interface Constrains Body Size in Whirligig Beetles
}

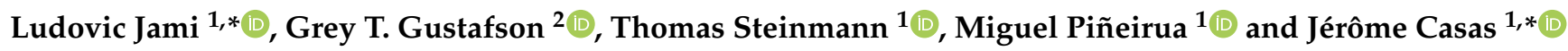 \\ 1 Institut de Recherche sur la Biologie de l'Insecte, UMR 7261, CNRS-Université de Tours, \\ 37200 Tours, France; thomas.steinmann@univ-tours.fr (T.S.); miguel.pineirua@univ-tours.fr (M.P.) \\ 2 Department of Biological Sciences, Northern Arizona University, Flagstaff, AZ 86011, USA; \\ gtgustafson@gmail.com \\ * Correspondence: jami@univ-tours.fr (L.J.); jerome.casas@univ-tours.fr (J.C.)
}

check for updates

Citation: Jami, L.; Gustafson, G.T.; Steinmann, T.; Piñeirua, M.; Casas, J. Overcoming Drag at the Water-Air Interface Constrains Body Size in Whirligig Beetles. Fluids 2021, 6, 249. https://doi.org/10.3390/ fluids 6070249

Academic Editor: Houshuo Jiang

Received: 2 June 2021

Accepted: 29 June 2021

Published: 6 July 2021

Publisher's Note: MDPI stays neutral with regard to jurisdictional claims in published maps and institutional affiliations.

Copyright: (c) 2021 by the authors. Licensee MDPI, Basel, Switzerland. This article is an open access article distributed under the terms and conditions of the Creative Commons Attribution (CC BY) license (https:// creativecommons.org/licenses/by/ $4.0 /)$.

\begin{abstract}
Whirligig beetles (Coleoptera: Gyrinidae) are among the best swimmers of all aquatic insects. They live mostly at the water's surface and their capacity to swim fast is key to their survival. We present a minimal model for the viscous and wave drags they face at the water's surface and compare them to their thrust capacity. The swimming speed accessible is thus derived according to size. An optimal size range for swimming at the water's surface is observed. These results are in line with the evolutionary trajectories of gyrinids which evolved into lineages whose members are a few milimeter's long to those with larger-sized genera being tens of millimeters in length. The size of these beetles appears strongly constrained by the fluid mechanical laws ruling locomotion and adaptation to the water-air interface.
\end{abstract}

Keywords: Gyrinidae; swimming insect; locomotion; water sliders; wave resistance; thrust; phylogeny

\section{Introduction}

Whirligig beetles are unique among the extant 176 families of beetles [1] in that they live, feed and socialize as adults on the surface on freshwater at the water-air interface. They display remarkable adaptations for this habitat including two pairs of eyes each adapted to vision in air and water [2,3], highly modified antennæ that detect surface vibrations [3] and potentially menisci [4], widened middle and hind legs that serve as a highly efficient rowing mechanism for swimming [5] and a body that spontaneously maintains itself at the interface thanks to buoyancy and capillary forces. Given their unique adult habitat and associated adaptations, gyrinids have long fascinated researchers and they show potential for bioinspiration [6-9].

When moving at the water-air interface, a whirligig beetle generates flows and characteristic surface waves [10]. In turn, the interface exerts resistance forces against the swimming beetle in the form of drags (Figure 1). Living on the surface of water exposes adult gyrinids to a variety of predators from both above the water's surface in the form of aquatic birds, as well as below, from aquatic predators like fish or other aquatic insects [11,12]. As a result, whirligig beetles are well known to form large surface aggregations that function as a selfish herd for defense against predation [13-16]. Consequently, whirligig beetles must be able to swim rapidly in order to both secure ephemeral prey items from the water's surface while in competition with other conspecifics [3]; as well as perform additional defensive maneuvers like flash expansion where individuals rapidly accelerate away from the center of an aggregation in order to cause predator confusion [16].

Therefore, fast swimming capability and the capacity to overcome drag are key for whirligig beetle survival. Morphological descriptions of the swimming appendages, as well as observations, analyses and modeling of the propulsion mechanism of aquatic beetles have been published by several authors [5,6,17-21]. Kinematics of whirligig beetles' trajectories and behavioral studies have also been reported [6,22-24]. However the costs and 
constraints associated with the semi-immersive swimming characteristic of whirligigs have not been fully reported and are the motivation for the present paper. In particular, the cost due to viscous drag experienced at water's surface has been repeatedly overestimated by supposition of its equivalence to the viscous drag in the water column [6,22]. Whirligig beetles differ from all other arthropods that live on the water's surface, as the latter walk on the water and are therefore not semi-immersed like whirligig beetles. The propulsion mechanism of surface walking insects has driven a large research interest resulting in the emergence of concepts and analyzing tools applicable to the study of locomotion at the water's surface [25-28].

The family Gyrinidae is diverse including 13 genera and $\sim 900$ known species (Supplemental Materials). Within this lineage there is relatively little morphological diversity with regards to much of their anatomy, particularly the ventral side, with the main differences associated with the form of the swimming legs of the early diverging Spanglerogyrus relative to all other Gyrinidae; and the uniquely conical abdomen with associated 'keel' of setae characteristic of the tribe Orectochilini, compared to the rounded and hairless abdomen of all other whirligigs [29]. However, there is large variation in size among Gyrinidae with the smallest species reaching $2.9 \mathrm{~mm}$ (Spanglerogyrus albiventris, see Figure 2b) and the largest $23 \mathrm{~mm}$ (Dineutus macrochirus). Thus, they span over an order of magnitude in terms of body length. This calls into question the particular role of size and scaling in whirligig beetle management of the resistance forces associated with the water-air interface.

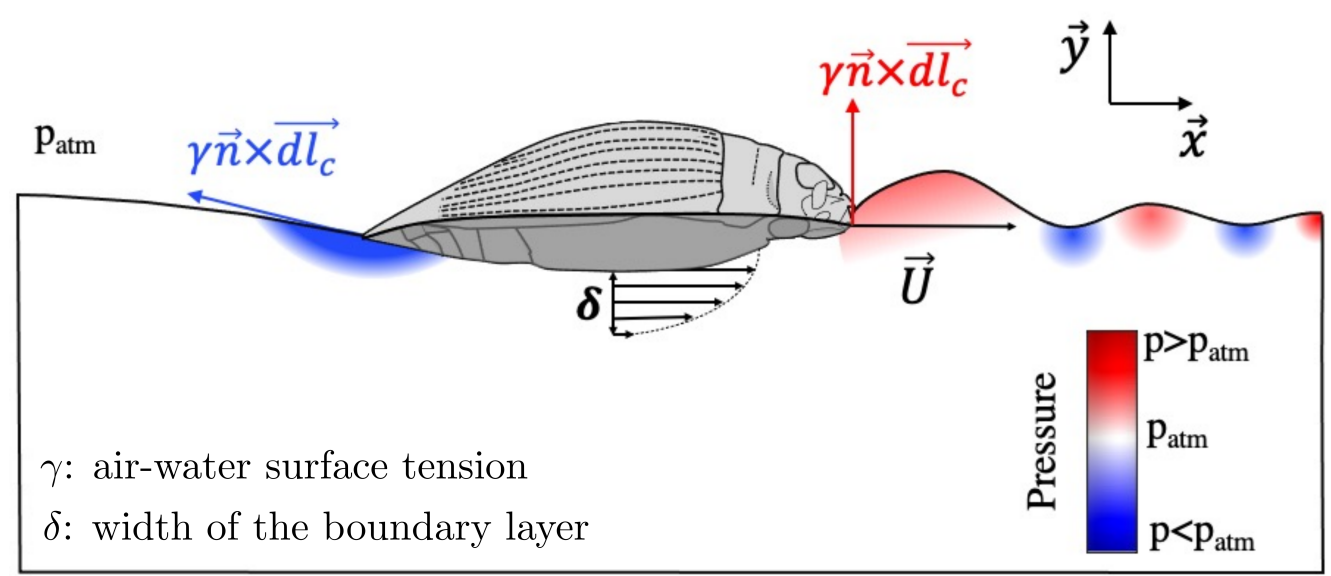

Figure 1. Scheme of the pressure field and the boundary-layer shear flow created by a moving whirligig beetle. Shear flow induces a viscous drag $R_{v}$ on the beetle. Waves generated by the beetle's movement are associated with an excess pressure field with overpressure (resp. underpressure) in the upper (resp. lower) region of the wave [30], as represented by the blue and red color fields. The pressure field and the local deformation of the interface exert forces on the beetle with horizontal and vertical components. The horizontal resultant corresponds to the wave resistance $R_{w}$ of the beetle. The beetle's body position is adapted so that the weight is compensated by the vertical resultant and body inclination adapt to cancel the moment of these forces. Hydrostatic pressure gradient is disregarded here. Pressure field force on the immersed surface $S_{i}$ reads $\int_{S_{i}} p d \vec{S}_{i}$ where $\overrightarrow{d S_{i}}$ is a vector equal to the element of immersed surface times the unit vector normal to the surface. Interface deformation force on the contact ligne $l_{c}$ reads $\int_{l_{c}} \gamma \vec{n} \times \overrightarrow{d l_{c}}$ where $\vec{n}$ is the local unit vector orthogonal to the interface and $\overrightarrow{d l}_{c}$ is the local element of the contact line oriented clockwise.

Due to the presence of the interface and the associated boundary conditions, the physics problem of semi-immersive locomotion is more complex than the analog bulk problem of a body fully immersed in a homogeneous fluid. The complexity of this fluid mechanical problem is still challenging under our current knowledge. For the concerned size and speed range, studies looking at both the air-water interface viscous drag and the wave resistance are limited. 
To make substantial progress concerning semi-immersive swimming of whirligig beetles, we computed a minimal model quantifying the role of size and scale on wave and viscous drags and compare it to their thrust capacity. We thus predict the constraints limiting the speed of species of different sizes. We compare these results with empirical data on gyrinids species' body sizes to show that our model captures the trends observed in these beetles adapted to life on the water's surface.
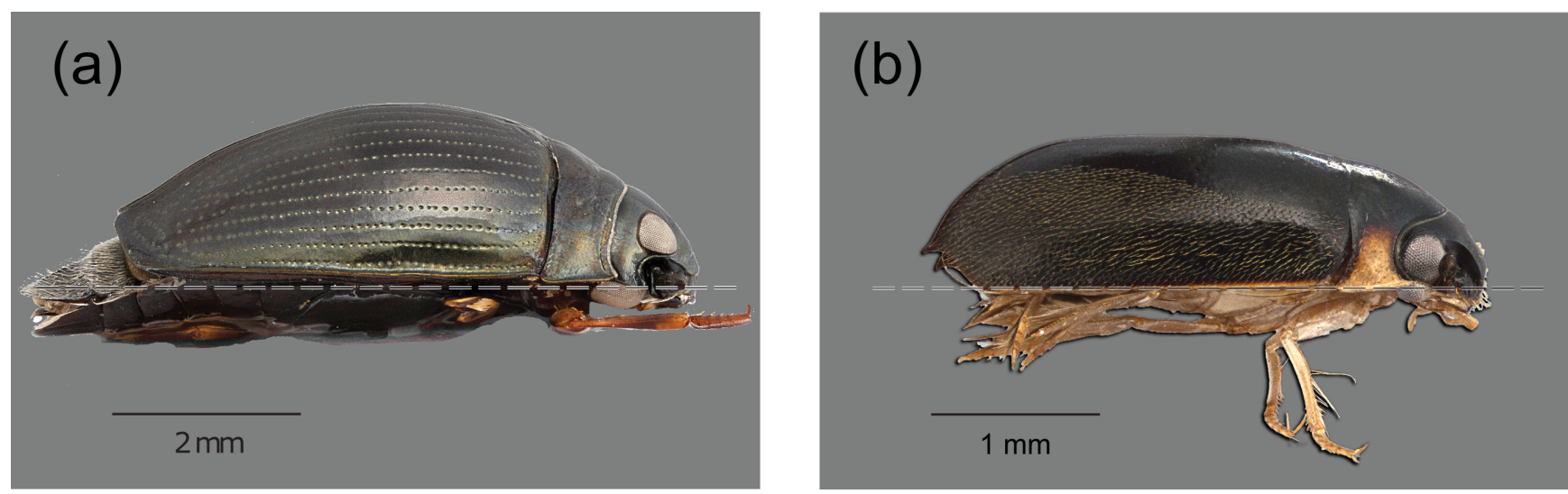

Figure 2. (a) Gyrinus dimorphus Régimbart deceased male in lateral view. Scale bar $=2 \mathrm{~mm}$. (b) Spanglerogyrus albiventris Folkerts deceased male in lateral view. Scale bar $=1 \mathrm{~mm}$. The dashed lines shows approximately where the water-line would sit on a living specimen.

\section{Scaling Drag Forces with the Insect Size}

The resistive forces faced when swimming at the water-air interface have two different physical origins. One is due to the emission of surface waves, called wave drag $R_{w}$. The other is due to the shear created by the insect in the fluid near its boundary layer (Figure 1). We will refer to the resistance induced by this creation of boundary-layer flow as $R_{v}$. In the present model, we compute these two forces $R_{w}$ and $R_{v}$ for simplified geometries and steady linear movement to describe the relationship between these two forms of drags and the speed and size of the insect.

\subsection{Wave Resistance}

Wave resistance is a complex resistance force as it varies non-monotonously with the speed of the body moving at the air-water interface. It originates from the upstream emission of capillary-gravity waves from the moving body. Indeed, mechanical perturbations on the water-air interface lead to the propagation of waves with a phase velocity $c_{\phi}=\left(\frac{g}{k}+\frac{\gamma k}{\rho}\right)^{1 / 2}$ where $k$ is the wave number, $g$ the gravity acceleration, $\rho$ the water density and $\gamma$ the surface tension of the water-air interface. $c_{\phi}$ reaches a minimum value $c_{\text {min }}=\left(\frac{4 g \gamma}{\rho}\right)^{1 / 4}=23 \mathrm{~cm} / \mathrm{s}$ for $\gamma=73 \mathrm{mN} / \mathrm{m}$. This minimum is reached for $k=\kappa=\sqrt{\frac{\rho g}{\gamma}}$, where $\kappa^{-1}$ is the capillary length. Therefore, the propagation of waves for speeds less than $23 \mathrm{~cm} / \mathrm{s}$ is prohibited. As a consequence, beetles moving slower than $23 \mathrm{~cm} / \mathrm{s}$ do not generate waves and thus experience no wave drag [30]. For a speed exceeding $23 \mathrm{~cm} / \mathrm{s}$, waves are emitted upstream meaning that the beetle transfers momentum to the water in the direction of its motion and therefore, according to momentum conservation, experiences a wave resistance. For beetles smaller than the capillary length $\kappa^{-1}=2.7 \mathrm{~mm}$, surface tension is the main restoring force, while for sizes larger than $\kappa^{-1}$, wave propagation is dominated by gravity effects. For infinitely high speed, waves are only emitted perpendicularly to the beetle's motion similarly to a "Mach-cone" [31], so that the wave resistance vanishes. This is why wave resistance's dependence on speed is non-monotonous and reaches a maximum for a finite speed. 
A rigorous theoretical description of the wave resistance due to 3D capillary-gravity waves was conducted first by Raphaël and de Gennes in the frame of linear wave theory [32]. They described the waves generated by the steady linear movement of a pressure disturbance of arbitrary shape on the water-air interface in the case of an ideal fluid. Since then, several extensions of this theory have been published to account for the depth-dependent current in water [33], fixed-depth perturbation of the interface [34], viscous dissipation of the waves [34], steady circular trajectories [35] or with sudden speed changes [36]. This framework has recently been used to describe the wave and the thrust generation of water strider insects (Hemiptera: Gerridae) [26]. Benzaquem et al. [37] also looked in detail at the effect of varying the size of the pressure disturbance on wave resistance. This theory has been validated experimentally for Leidenfrost droplets sliding on the water's surface [38]. Burghelea and Steinberg [39] conducted an experiment with solid disturbances on the air-water interface thus closer to the reality of whirligig beetles. Their measurements were inconsistent with Raphaël and de Gennes theorical results, but it has been argued that Burghelea and Steinberg set-up led to the observation of boundary effects due to the narrowness of the channel containing the water and which were not taken into account in the proposed theory $[34,39]$.

Here we propose a description of the wave resistance experienced by a whirligig beetle with a steady linear movement as being the one for a pressure disturbance $P(r)$ of gaussian form specifying the characteristic size of the beetle:

$$
P(r)=\frac{F_{0}}{2 \pi b^{2}} \exp \left(-\frac{r^{2}}{2 b^{2}}\right)
$$

where $b$ is half the length of the beetle and $r$ is the radial coordinate in the water-air interface plane. The wave resistance is then given by [32,37]:

$$
R_{w}=\frac{F_{0}^{2}}{\pi \gamma} \int_{0}^{\chi} \mathrm{d} \theta \cos \theta \frac{k_{+}(\theta)^{2} e^{-b^{2} k_{+}(\theta)}+k_{-}(\theta)^{2} e^{-b^{2} k_{-}(\theta)}}{k_{+}(\theta)-k_{-}(\theta)},
$$

where $\chi$ is defined by $\cos \chi=\frac{c_{\min }}{V}, V$ being the forward beetle speed and:

$$
k_{ \pm}(\theta)=\kappa\left(\frac{V}{c_{\min }}\right)^{2}\left(\cos ^{2} \theta \pm\left(\cos ^{4} \theta-\cos ^{4} \chi\right)^{1 / 2}\right) .
$$

For whirligig beetles, the pressure force $F_{0}$ corresponds to the weight of the beetle. Thus, there is an indirect dependence on the insect's size through $F_{0}$. Supposing a constant density $\rho_{b}\left(\sim 1000 \mathrm{~kg} / \mathrm{m}^{3}\right)$ of the insect over its size range and a simple insect spherical geometry, the pressure force gives:

$$
F_{0}=\frac{4}{3} \pi b^{3} \rho_{b} g
$$

This dependence of the pressure force $F_{0}$ on the insect's size $b$ has a major impact on the magnitude of the wave resistance. Variations in size are amplified to the power of 6 for the wave resistance. This simply reflects the fact that bigger beetles have a larger weight, thus they deform the interface to a greater extent and generate waves with larger amplitudes, thereby increasing the wave drag. This scaling of the pressure force is the major difference between our work and the wave resistance analysis of Benzaquem et al. [37], who analyzed the impact of the perturbation size $b$, keeping the perturbation pressure force $F_{0}$ constant.

Figure 3 shows the variation of the wave resistance with the size and speed of whirligig beetles. The size and speed ranges represented are larger than the observed sizes and speeds of all whirligig beetles, but help to illustrate the physics of wave resistance. As shown in Figure $3 \mathrm{a}-\mathrm{f}$, the $R_{w}$ profile as a function of speed displays a peak for any insect size. 
The magnitude and shape of the peaks greatly vary with size. For example, between the graphics a to $f$ of Figure 3, the range of size considered varies over one and a half order of magnitude while the magnitude of the wave resistance span over six orders of magnitude.
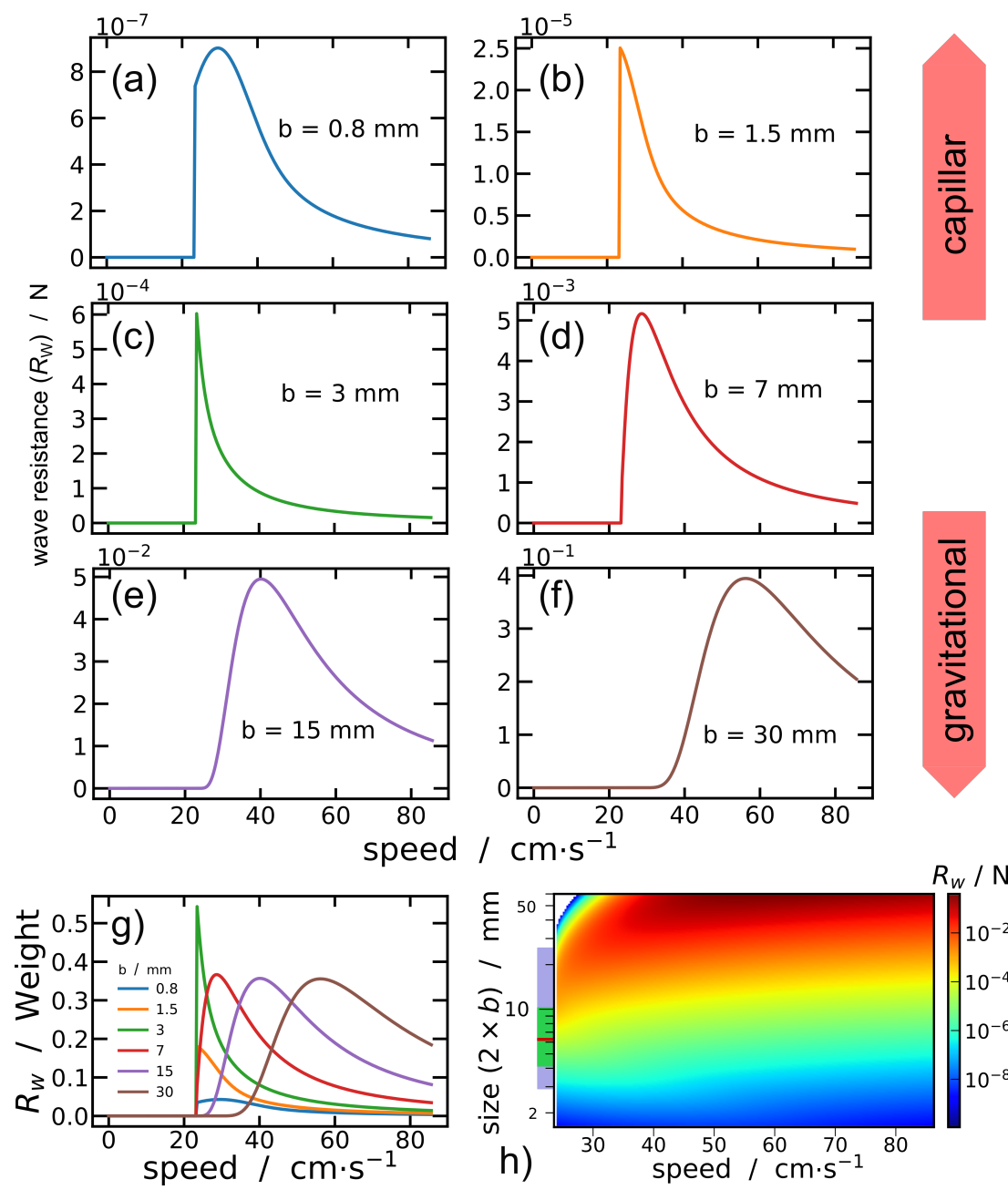

Figure 3. Wave resistance $R_{w}$ as a function of speed for different sizes of whirligig beetles (a-f). Note that there roughly a difference of a factor of ten for $R_{w}$ between each consecutive size. From figure (a-f), waves change from a capillar to a gravitational regime. $(\mathrm{g}) R_{w}$ divided by the weight of the insect. (h) $R_{w}$ as a function of the insect's size and speed (log scale for the size and $R_{w}$ ). The range of sizes of whirligig beetles is highlighted in light blue on the axis, the green rectangle indicates the standard deviation of the size distribution around the mean, and the red line indicates the median.

The surface wave resistance model of Raphaël and De Gennes initially considered a disturbance not in contact with the water, and simply computed the wave resistance by summing the force needed to create the waves pattern generated by the pressure disturbances. In the case of whirligig beetles, as well as for other solid disturbances, one can wonder how this resistance is transmitted to the moving body. Following Steinmann et al. [25], we attempt to give an intuitive explanation of the mechanism of transmission of wave resistance. In quasi-static condition, at fixed cruising velocity, a high pressure zone develops at the front of the body. The resulting change in pressure across the water-air interface leads to the appearance of a bow wave when the velocity exceeds $23 \mathrm{~cm} / \mathrm{s}$ (Figure 1). The decrease in pressure at the back of the body tends to flatten the surface, leading to an asymmetry of the contact angles at the front and the back of the insect. This results in a non-zero capillary force acting on the contact line, at the junction of the body and the interface. The asymmetric pressure field also exerts a force by acting normally on the immersed surface. Thus, the insect delivers momentum to the fluid from the action of its 
pressure force on the interface and it is the asymmetrical pressure field and contact angles created that bring back this wave-making force to the body. Pressure force dominates over surface tension force for bodies larger than the capillary length.

\subsection{Viscous Drag}

Viscous drag $R_{v}$ is a more common hydrodynamic drag and is well known for objects immersed in a fluid [40] and was thoroughly studied by Nachtigall for bodies of aquatic beetles fully immersed [18]. This drag can have very different characteristics depending whether the flow created around the body (the boundary layer) is laminar or turbulent as a function of the body shape. For a laminar flow viscous drag is created by tangential shear stress while for turbulent flows viscous drag is mainly induced by normal pressure stress. The laminar or turbulent nature of flows is generally characterized by the Reynolds number $R e=\frac{V b}{v}$ where $v=10^{-6} \mathrm{~m}^{2} / \mathrm{s}$ is the water kinematic viscosity. The Reynolds number for gyrinids' typical speed and size range is around $10^{3}$.

Voise and Casas [22], and later on $\mathrm{Xu}$ et al. [6], supposed that a whirligig beetle swimming at the surface was experiencing a turbulent viscous drag analogous to that of a immersed beetle swimming in the water column [18]. For a beetle of characteristic size $\mathrm{b}$, this viscous drag reads $R_{v}^{b u l k}=\frac{C_{f}}{2} \rho V^{2} 4 \pi b^{2}$, where $C_{f}$ denotes the friction coefficient. For Re around $10^{3}, C_{f}$ can be considered constant and equal to 0.3 over the range of whirligig beetle size and speeds $[18,40]$.

However, when swimming at the surface, whirligig beetles experience a different viscous drag than when they swim in the water column, as less water is displaced. They indeed swim faster at the surface [18]. Xu et al. [6] measured the average depth of the submerged portion of some whirligig beetles and found $0.74 \mathrm{~mm}$ for an average beetle of size $5.23 \mathrm{~mm}$. Thus, only a very small fraction of the beetle's body is immersed as can be seen for Gyrinus and Spanglerogyrus specimens in Figure 2 (see also [21]). Indeed, the typical whirligig beetle shape shows a small curvature for its submerged part so that boundary-layer separation should be prevented and pressure stress minimized. Therefore the modeling of $R_{v}^{b u l k}$ for viscous drag when swimming at the surface does not seem to fit.

Thus, a more reasonable model is to instead consider these beetles as sliders, in contact with water through a flat surface only. For Reynolds numbers lower than $10^{5}$, Blasius laminar boundary-layer theory can be applied to describe such viscous drag dominated by shear stress. Indeed, the viscous drag experienced by a disc of radius $b$ sliding on the surface has been studied experimentally by Pucci et al. [41]. They obtained a very good agreement with the following Blasius theoretical expression:

$$
R_{v}^{\text {slide }}=1.64 \rho \sqrt{v} b^{3 / 2} V^{3 / 2}
$$

Drag models described by $R_{v}^{\text {bulk }}$ and $R_{v}^{\text {slide }}$ formula differ in important ways, $R_{v}^{\text {bulk }}$ being greater by a factor of 5 to 30 in the range of sizes and speeds at stake. Moreover, size and speed scale with a power 2 in $R_{v}^{b u l k}$ and with a power of $3 / 2$ in $R_{v}^{\text {slide }}$, giving different asymptotic behaviors. $R_{v}^{b u l k}$ can be seen as an upper limit for the viscous drag, where more energy is dissipated by turbulence, while $R_{v}^{\text {slide }}$ can be seen as a more faithful model for the actual viscous drag experienced by these insects swimming at the water-air interface. Thus, we model the viscous drag using the $R_{v}^{\text {slide }}$ formula in the following sections.

\subsection{Total Drag}

The fluid flow and the waves created by these semi-immersive swimmers can be considered independent of each others. Thus the total drag experienced by whirligig beetles is given by the sum of both the viscous and wave drag. In Figure 4 we show the sum of $R_{w}+R_{v}^{\text {slide }}$ (given in Equations (3) and (5)) to illustrate the scaling of the total drag with size and speed. For smaller sizes, the viscous drag dominates while the wave drag dominates for larger sizes as a consequence of the different size scaling of the two forces. Figure $4 \mathrm{c}$ displays a local minimum for the total drag for a speed equal to $37 \mathrm{~cm} / \mathrm{s}$ similar 
to what Voise and Casas predicted [22]. In their work, they studied the kinematics of legs beating of swimming whirligig beetle of the species Gyrinus substriatus of $6 \mathrm{~mm}$ size. They observed three different stroke patterns for the leg kinematics, the third type being associated with high speed regimes $(>23 \mathrm{~cm} / \mathrm{s})$. Voise and Casas argued that the high speed regime associated with type III leg kinematics corresponds to a local minimum of the total drag. But in contrast to our model, they supposed a turbulent viscous drag $R_{v}^{b u l k}$, thus overestimating this drag.
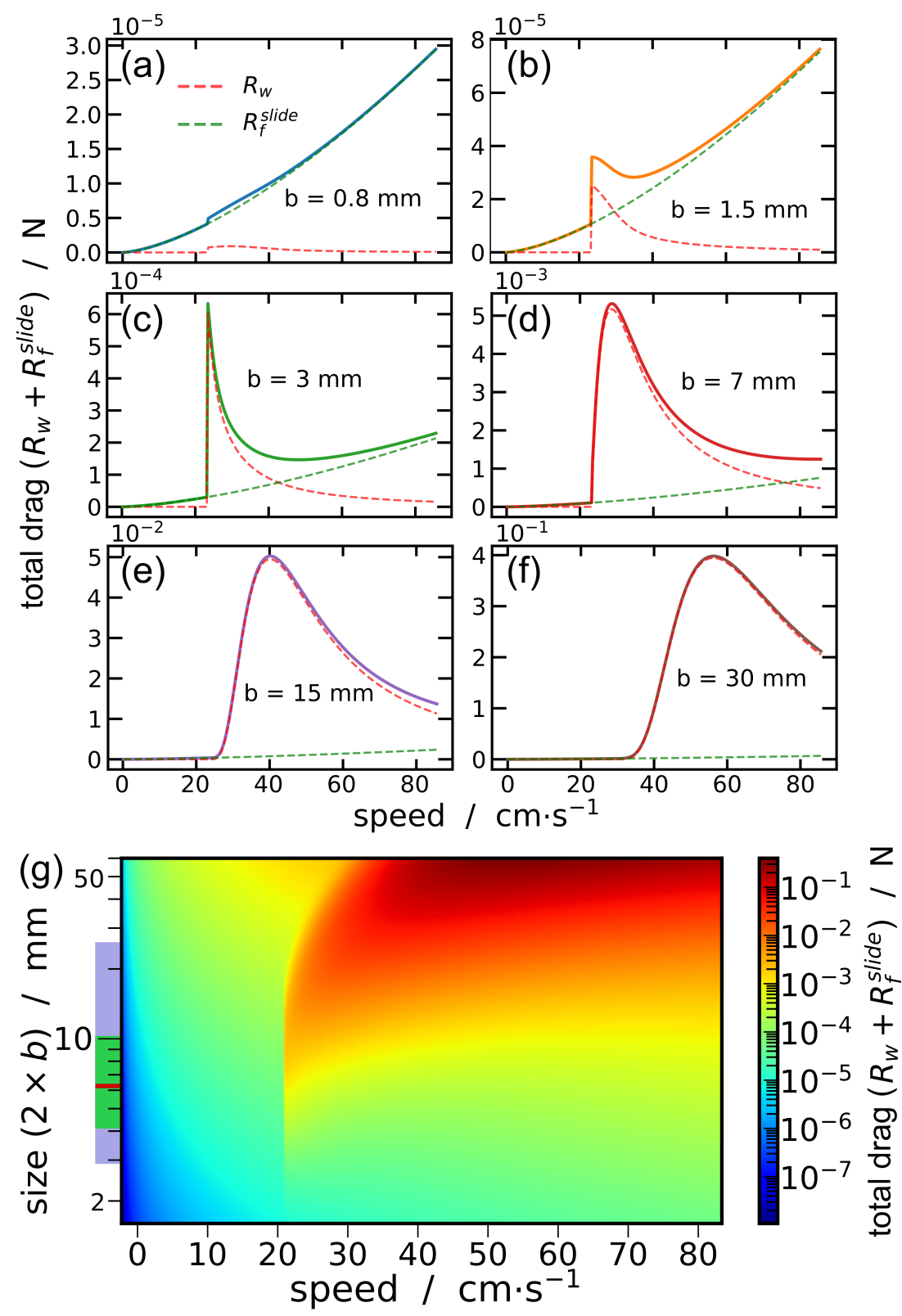

Figure 4. Total drag as a function of the insect's speed for different sizes $(\mathbf{a}-\mathbf{f})$. The total drag is the sum of the wave and the viscous drag (Equations (3) and (5)). (g) Color map of the the total drag as a function of size and speed. The range of sizes of whirligig beetles is highlighted in light blue on the axis, the green rectangle indicates the standard deviation of the size distribution around the mean, and the red line indicates the median.

\section{Scaling of the Insect Thrust Capacity and Comparing It with Drag}

As we showed, the drag experienced by whirligig beetles of different sizes can strongly vary, but the relevance of these results can only be unraveled by comparing them to the thrust capacity of the insects. Animal locomotion is often characterized by specific scaling 
as a result of the physical constraints at play. For example, undulatory swimmers exhibit thrust to drag ratios that follow universal scaling laws for a wide variety of species of different sizes [42]. Two physical constraints can be expected to limit the thrust capacity of swimming whirligig beetles: the limited propulsion force that its locomotor apparatus can support and the limited power that gyrinids can provide for locomotion.

\subsection{Scaling of Maximal Thrust Force}

According to Marden and Allen [43,44], there is a universal scaling of the maximal average force of cyclic locomotor motors. For multiaxial motors, the maximal force is observed to scale linearly with the motor's mass as a result of a trade-off between maximizing the force and a sufficiently long motor lifespan. This scaling is observed for very different materials and motor mechanisms and all data fall around a motor mass-specific force of $57 \mathrm{~N} / \mathrm{kg}$. Even though this scaling wasn't tested for the rowing locomotion as used by whirligig beetles, they both obey the same general physical constraints thought to give rise to this scaling. Thus we model the maximal capacity of steady thrust of the whirligig beetle according to Marden and Allen's scaling. Aside from their analysis, this scaling of the thrust can be seen as a simple adequacy of the force of the whirligig beetle with its mass, which seems a justified first guess for the thrust capacity. This is also supported by the linear scaling of the musculature of coleopterans with their volume [45].

A maximal swimming speed of $50 \mathrm{~cm} / \mathrm{s}$ was observed by Voise and Casas for the $6 \mathrm{~mm}$ long Gyrinus substriatus [22] $(b=3 \mathrm{~mm})$. Following our model, the total drag experienced at this size and speed is $1.1 \mathrm{mN}$. This gives a mass-specific force of $5.4 \mathrm{~N} / \mathrm{kg}$. Therefore, according to Marden et Allen's universal scaling, it supposes that the swimming muscles represent $10 \%$ of the whirligig beetle's mass. This supposition seems reasonable [45], even if one were to consider that the overall muscle mass of gyrinids is reduced due to the reduction of flight musculature $[17,21]$. The maximal thrust that can be maintained by whirligig beetles of different sizes can then be extrapolated from this results:

$$
F_{\max }=R_{0} \frac{b^{3}}{b_{0}^{3}}
$$

where $R_{0}$ is the total resistance experienced by a whirligig beetle of typical size $b_{0}=3 \mathrm{~mm}$ moving at $50 \mathrm{~cm} / \mathrm{s}$. $F_{\max }$ must be interpreted as the maximal averaged over swimming cycles.

We represent the ratio of the total drag to the maximal thrust as a function of insect size and speed in Figure 5. For all sizes considered, a ratio lower than 1 indicates that the speed is accessible for whirligig beetles while a ratio higher than 1 indicates a speed regime that can only be temporary accessed but not maintained. Swimming whirligig beetles have an oscillating speed around an average value because their rowing propulsion mechanism is discontinuous [22]. The resistance and thrust presented in Figure 5 can thus be understood as average values over their swimming beat cycles. 


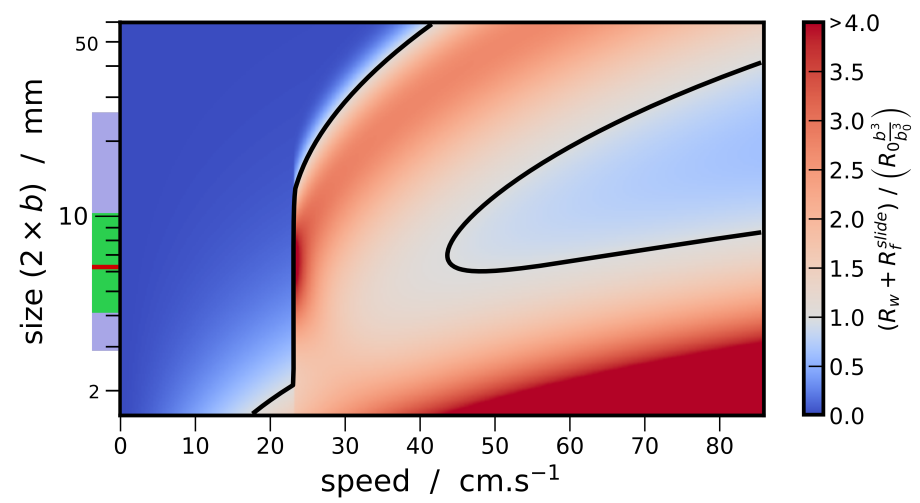

Figure 5. Total $\operatorname{drag}\left(R_{w}+R_{v}^{s l i d e}\right)$ divided by the putative propelling force a whirligig beetle can exert $\left(R_{0} \frac{b^{3}}{b_{0}^{3}}\right)$ as a function of its size and its speed. The black line indicates where the total drag equals the insect's thrust. Thus the blue region where the drag-thrust ratio is below 1 delimits the speeds accessible. The range of sizes of whirligig beetles is highlighted in light blue on the axis, the green rectangle indicates the standard deviation of the size distribution around the mean, and the red line indicates the median.

\subsection{Thrust Power}

Following the work of Nachtigall and Blake on the rowing mechanism of swimming beetles $[5,18,19]$ we propose a simplified mechanical model for the swimming of whirligig beetles. Nachtigall demonstrated that most of the thrust force was transmitted mostly by hind legs when they are perpendicular to the insect body and that the resistance due to the return phase of the legs motion was negligible [5]. Accordingly, Figure 6 present a simplified scheme of the whirligigs' oars apparatus. The propulsion force therefore created reads:

$$
T=2 \frac{1}{2} \rho C_{f}^{l e g} H \int_{0}^{R}(\omega r-V)|\omega r-V| \mathrm{d} r=\frac{\left(R^{2} \omega^{2}-R V \omega+V^{2}\right)(R \omega-2 V) C_{f}^{l e g} H \rho}{3 \omega},
$$

where $\omega, C_{f}^{l e g}, R$ and $H$ are respectively the angular speed, the friction coefficient, the length and the width of the oars and $r$ is the coordinate along the oars length. In the following we assumed that $R=b, H=b / 2$ and $C_{f}^{l e g}=1.1[5]$.

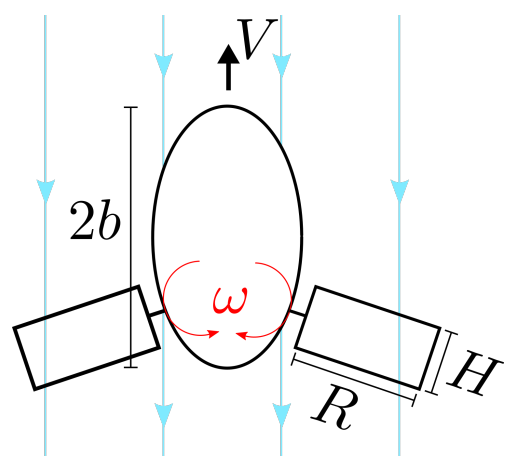

Figure 6. Simplified scheme of oars apparatus of whirligig beetles.

The angular speed of the oars $\omega$ necessary to maintain a given speed can be found by solving the equilibrium of drags and thrust $T=R_{w}+R_{v}^{\text {slide }}$, the result as a function of the insect size and speed is plotted in Figure 7a. The power work necessary to put the oars in motion is:

$$
P_{T}=2 \frac{1}{2} C_{f}^{l e g} H \omega \int_{0}^{R}(\omega r-V)|\omega r-V| r d r=\frac{\left(3 R^{2} \omega^{2}-8 R V \omega+6 V^{2}\right) R^{2} \omega^{2}-2 V^{4}}{12 \omega} C_{f}^{l e g} H \rho
$$


In Figure $7 \mathrm{~b}$ we plotted the rowing thrust power required to maintain a constant speed divided by beetle mass (specific thrust power) as a function of size and speed. Specific thrust power that a whirligig beetle can deliver is limited as a consequence of the limited power of muscle fibers themselves.
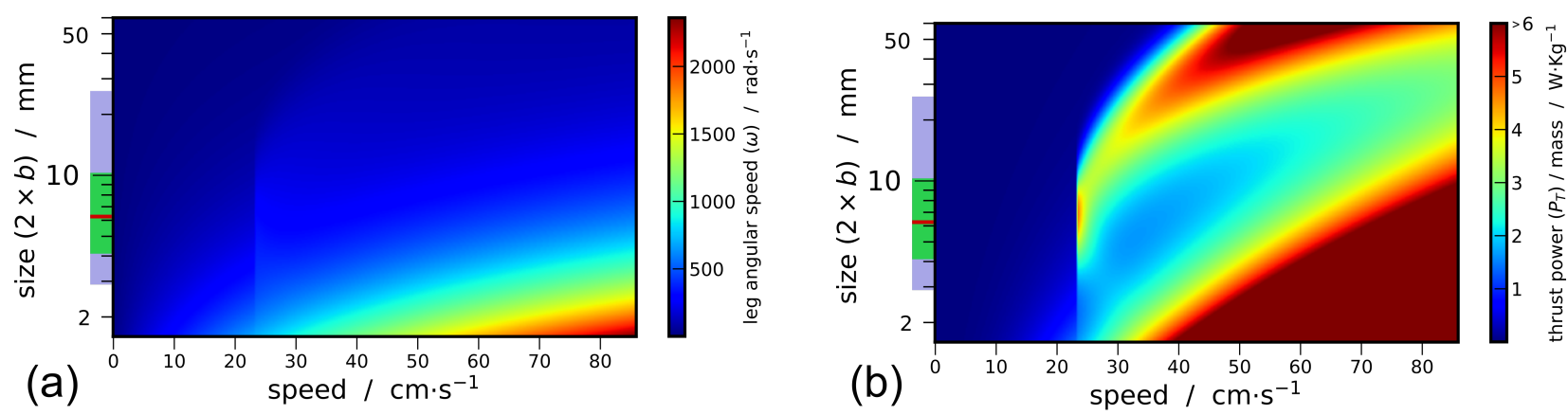

Figure 7. (a) Angular speed of whirligig beetles' legs required to maintain a certain speed and (b) required specific thrust power as function of size and speed of the whirligig beetle. The range of sizes of whirligig beetles is highlighted in light blue on the axis, the green rectangle indicates the standard deviation of the size distribution around the mean, and the red line indicates the median.

\subsection{Synthesis}

As illustrated in Figure 8, our model for the scaling of the drags and the thrust capacity of whirligig beetles predicts that:

(i) Beetles of a size length smaller than $2 b_{\min }=6 \mathrm{~mm}$ cannot achieve a high speed regime $(>23 \mathrm{~cm} / \mathrm{s})$. Indeed for these small sizes, the viscous resistance exceeds the wave resistance. The ratio comparing drag and thrust then reads, $\frac{R_{t o t}}{\text { Thrust }} \simeq \frac{R_{l}^{\text {slide }}}{R_{0} b^{3} / b_{0}^{3}} \sim\left(\frac{V}{b}\right)^{3 / 2}$ and diverges as size decreases and speed increases. With an upper estimation of $15 \%$ for the muscle mass ratio of whirligig beetles, $2 b_{\min }$ reduce to $3 \mathrm{~mm}$.

(ii) Larger-sized insects, between approximately 6 and $13 \mathrm{~mm}$, can achieve high speed regimes but cannot maintain themselves in a middle-range speed where the wave resistance reaches its maximum. As explained previously, the avoidance of intermediate speeds has been observed and partially explained by Voise and Casas [22].

(iii) This size range insects, when reaching speed beyond wave resistance peak, have a maximal speed limited by the specific thrust power required increasing with speed.

(iv) As size increases, the wave resistance peak widens, thereby a greater thrust effort is likely needed to overcome this peak. Therefore, it should be less probable for the largest whirligig beetles to reach the high speed regime where the wave resistance is greatly reduced. Furthermore, the onset of the wave resistance moves to higher speeds with $V_{\text {onset }} \sim \sqrt{g b}$. Thus the largest species still reach relatively large speeds around $33 \mathrm{~cm} / \mathrm{s}$ below wave resistance peak.

This last prediction is semi-quantitative because a proper evaluation of the effort needed to cross the wave resistance peak falls beyond the scope of this paper. It indeed requires study of the drag experienced with unsteady trajectories and the burst acceleration capacity of whirligig beetles. Nevertheless, we can compute the work $W$ needed to overcome the inertial gap between $V_{\text {onset }}$ and $V_{\text {offset }}$, which are respectively the speeds at which drags overcome thrust and at which thrust overcomes drags (Figure 5). Then with, $W=\frac{m_{b}}{2} \Delta V\left(\Delta V+2 V_{\text {onset }}\right)$ where $\Delta V=V_{\text {offset }}-V_{\text {onset }}$, we can see that it increases for bigger sizes because $\Delta V$ and $V_{\text {onset }}$ increases as already mentioned. Here $m_{b}$ is the mass of the beetle. Because $W$ increases with insect size, the time spent to overcome the resistance peak should also increase. During this time, a high proportion of the energy spent is lost in overcoming drag. The magnitude of the wave resistance peak compared to the thrust of the insect might play a role in this loss. But as shown in Figure $3 g$, for insect sizes between 3 and $30 \mathrm{~mm}$, peak magnitude varies relatively less than the widths of peaks. 


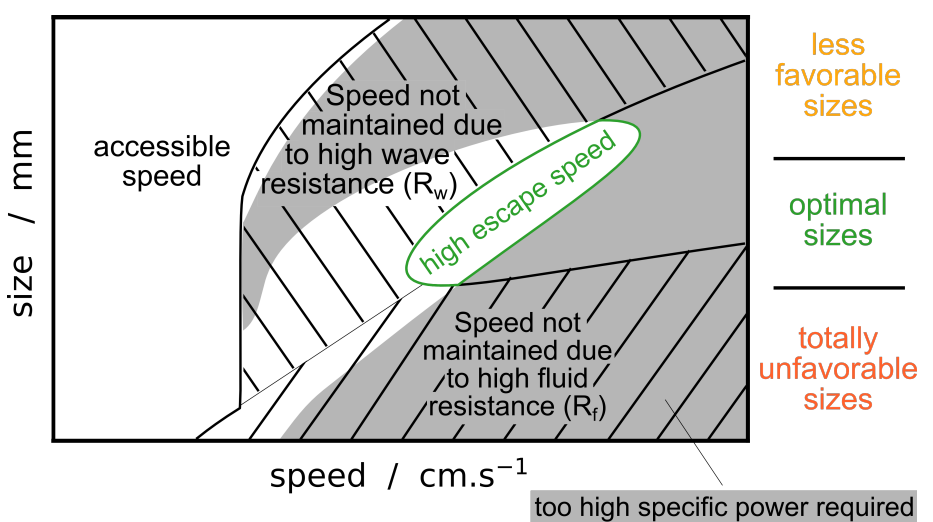

Figure 8. Scheme of the constraints that limits whirligig beetles water-air interface locomotion.

Voise and Casas [22] observed a dichotomy in speed regimes of $6 \mathrm{~mm}$-long whirligig beetles due to the avoidance of the wave resistance peak. Similar studies on species of larger sizes may reveal the absence of such a dichotomy and a maximal speed lower than smaller species as the wave resistance peak is not crossed.

We think that because of the simplified geometries, parameter estimations and scaling models considered here, the wave drag, the viscous drag and the thrust may vary relatively within a factor 2 or 3 but the broad picture given by Figure 8 describing the main mechanisms at stakes should hold tight.

The size scaling of locomotion at air-water interface, presented here and in the previous section for whirligig beetles, have consequences beyond the gyrinid realm and relates more broadly to such locomotion over a wider range of sizes [28].

\section{Significance for Gyrinidae Ecology and Evolution}

As discussed in the introduction, fast swimming regimes are under strong selective pressure and accessing high speed at low cost is favorable as it enables gyrinids to efficiently secure food while avoiding predators. Figure 5 shows that the resistances associated with swimming at the water-air interface and the thrust capacity of the insects in question determine the speed at which they can move. Depending on a whirligig beetle's size, the speed regimes that it can access vary. Therefore, due to the different scaling laws at play regarding the insect's thrust and drags, the cost of locomotion and its impact on fitness should vary among different species. To discuss this hypothesis, we now compare our results to the size distribution of all species of whirligig beetle. Supposing this hypothesis true and given the result of our model, we would predict: (1) that natural selection would favor whirligig beetle sizes capable of achieving high swimming speeds resulting in the body lengths of most gyrinid species being clustered around the optimal sizes shown in Figure 8, with body lengths outside this range being less common; and (2) a whirligig beetle smaller than a threshold (a few $\mathrm{mm}$ ) would experience too high viscous resistance rendering it incapable of fast swimming and therefore would be heavily selected against.

To test these hypotheses, we now compare our results to the size distribution of all known living species of whirligig beetles and the family's fossil record. Figure 9 shows histograms of the minimal recorded body length for all extant members within a genus for all genera of whirligig beetle with at least 26 or more constituent species. Consistent with our first prediction, most species' body length's concentrate below $10 \mathrm{~mm}$ but above $3 \mathrm{~mm}$. Indeed, the four genera with the highest number of species, Gyretes, Orectogyrus, Patrus and Gyrinus all concentrate in this range of sizes. This suggests that natural selection has primarily favored the evolution of whirligig beetles within this size range (note that the maximal size of a whirligig beetle genus rarely exceed $140 \%$ of its minimal size). Consistent with this, throughout most of the evolutionary history of whirligig beetles (i.e., over $\sim 118 \mathrm{Ma}$ ), body length has remained between this optimal size range (Figure 10). Only relatively recently, after the Mesozoic, are large body sizes over $10 \mathrm{~mm}$ explored within members of the Dineutini and Orectochilini clade. Presently, only the dineutine 
genera Dineutus and Macrogyrus exhibit regularly large body sizes with a median over $10 \mathrm{~mm}$ (Figure 9). The relatively smaller body sizes (i.e., those below $10 \mathrm{~mm}$ ) of whirligig beetles concentrate around medium body lengths (between 5 to $9 \mathrm{~mm}$ ) with a median of $6.25 \mathrm{~mm}$, as if small sizes (i.e., those below $5 \mathrm{~mm}$ ) were less favored. In support of our second prediction, a whirligig beetle smaller than $2.9 \mathrm{~mm}$, the length of the extant Spanglerogyrus albiventris (Figure 2 b), is currently unknown and has never been known to occur (Figures 9 and 10).

In line with natural selection acting strongly upon the size of whirligig beetles, body lengths have remained stable within most whirligig beetle lineages over hundreds of millions of years of evolution. For instance, all known Spanglerogyrinae, which represent the earliest diverging lineage of Gyrinidae, are small-bodied being between $\sim 3 \mathrm{~mm}$ to at most $4.5 \mathrm{~mm}$ and have remained this way for at least $176 \mathrm{Ma}$ (i.e., the minimum age estimate for the fossil Angarogyrus minimus Figure 10). Among the Heterogyrinae, which includes the monotypic Malagasy striped whirligig, Heterogyrus milloti [46], the oldest known fossil species, the Jurassic Cretotortor sp. at $\sim 179$ Ma [46,47], is very similar in size to the aforementioned single modern species. More interesting, despite the fact that the Heterogyrinae subfamily appears to have been the dominant whirligig beetle lineage throughout the Mesozoic [46], this lineage does not exhibit the exploration of body size seen in the Dineutini + Orectochilini clade, instead remaining within the optimum mediumsize body lengths (Figure 10). The overall anatomy of both the Spanglerogyrinae and Heterogyrinae shows a similar pattern, having remained little changed since the Early Jurassic [46]. The same goes for the tribe Gyrinini, in that they have remained primarily medium-sized, with a few species exhibiting small body lengths, but this latter lineage suffers from a largely incomplete fossil record (Figure 10). As noted above, within Dineutini and Orectochilini, evidence for the evolution of body lengths over $10 \mathrm{~mm}$ does not occur until after the Cretaceous, with the only known adult Cretaceous dineutine, Cretodineutus rotundus, exhibiting a medium-sized body length of $7 \mathrm{~mm}$ [48]. This delayed exploration of large body size could be a result of release from competition with the only other surfacedwelling aquatic beetle known family to have existed: the extint Coptoclavidae-distant relatives of whirligig beetles [49], that persisted from the Triassic until the Early Cretaceous and included common large-bodied forms like Coptoclava longipoda which was over $39.1 \mathrm{~mm}[50]$.

As large-sized whirligig beetles are still theoretically capable of reaching high swimming speeds over $23 \mathrm{~cm} / \mathrm{s}$, but likely below the wave resistance peak, their evolution could be favored given certain additional conditions. For example, larger body sizes may be favored for diving capabilities because their higher thrust capacity enables them to reach higher speeds underwater. Underwater viscous drag versus thrust scales as $\frac{R_{v}^{b u l k}}{F_{\max }} \sim \frac{V^{2}}{b}$ and thus, indeed decreases with the insect's size. Therefore, the large whirligig beetle species may compensate the higher cost of their interface locomotion with better underwater swimming capability. In line with this, certain species of Dineutus (i.e., D. indicus and D. sinuosipennis) and Macrogyrus (M. oblongus) are known to also swim within the water column (Gustafson pers. obs. and [51]). This is in stark contrast to small body sizes. Our model provides a possible explanation for why the evolution of a very small whirligig beetle is fundamentally impossible given the inability to overcome viscous drag and swim rapidly at the air-water interface. Small sizes are also limited when diving due to higher viscous drag. 


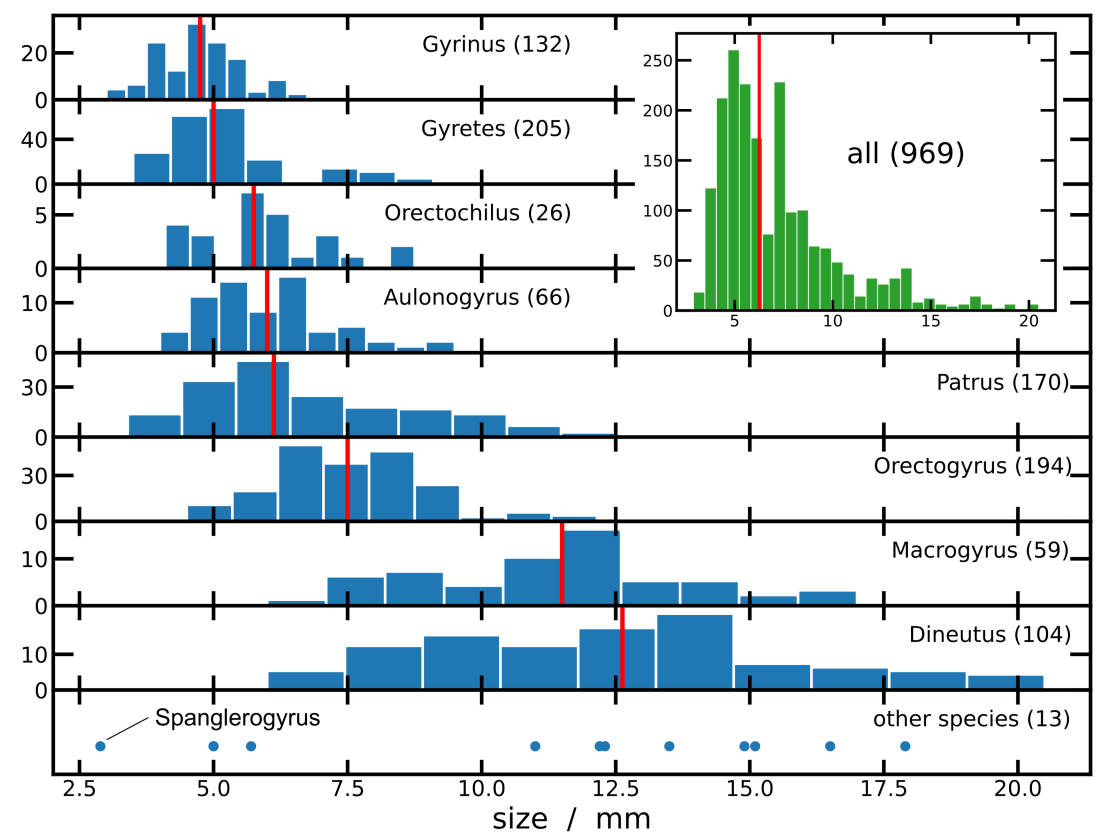

Figure 9. Histograms of species minimal sizes for the different genera of whirligig beetle ranked according to median minimal size. Lower panel points the minimal sizes of the species belonging to genera with only few species. Inlet show the histogram of the minimal sizes of all whirligig beetle species. Number of species composing the histograms are indicated in brackets. A red line indicates the median.

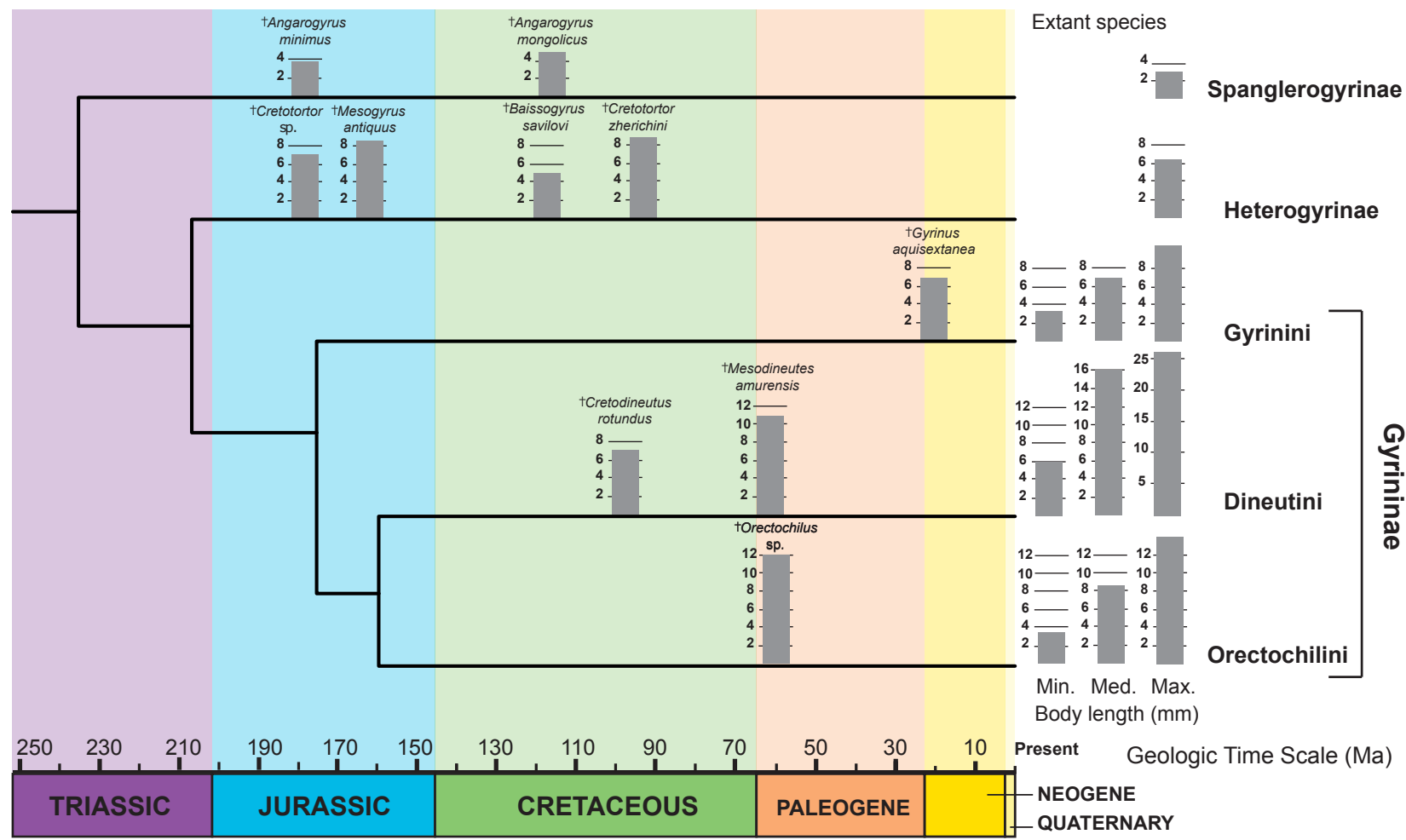

Figure 10. Time calibrated phylogeny showing the evolutionary history of whirligig beetles and their relationships based on Gustafson et al., 2017 [46]. Fossils are placed where they occur in the geologic record based on their median age above the branch of the tree to which they belong. Fossils were chosen from throughout fossil record for each lineage based on whether preservation was enough to estimate body length. The histogram for fossil taxa shows maximum body length, while those for the living species with more than one representative shows the minimum, median, and maximum sizes. 


\section{Perspectives}

The presented modeling of resistances and thrust capacity of gyrinids, although minimal, predicts the main constraints involved in the adaptation to air-water interface locomotion and helps to identify the priority for future work to improve our knowledge of such a life style. This is a challenging task requiring multidisciplinary research from both physicists and biologists. Insightful results should be found in the experimental testing of our model's predictions as well as in the extension of the modeling of the physical mechanisms. Such investigations could have major consequences for improving our understanding of gyrinid evolution and for bioinspiration of air-water interface locomotion.

Physical understanding of the resistances at stakes could be improved. PIV measures or numerical simulation of the flow around semi-immersed object are currently missing. Whether the flow is laminar or turbulent induces a change in the viscous resistance, from $R_{v}^{\text {slide }}$ to $R_{v}^{b u l k}$, with significant consequences for the description of gyrinid's locomotion. Measures of the wave resistance of semi-immersed solid objects are also lacking. The effect due to the presence of the body-to-surface contact line and the water non-slip boundary condition at the immersed surface are not yet clarified. Whether the wave resistance mainly transmits through surface tension or pressure field, depending on the object form is also an open question.

The work presented here also identifies the need for more behavioral studies on whirligig beetle swimming capabilities with regards to species' size and the levels of speed attainable. Our results suggest that species whose size prevents them from reaching high swimming speeds due to water-interface constraints on locomotion are likely to have specific adaptations for off-setting such constraints. For example, they may exhibit greater capabilities for diving, or structures that aid in reducing drag. Identifying these will further help understand whirligig beetle adaptations with great potential for improving designs based upon biomimicry. But, so far, tracking data and analyses are not widely available. Additionally, reporting variation in size, mass and shape of the whirligig beetles will be important for further characterizing locomotor performance, as demonstrated by our model. Measurements of escape speeds by simulating chase conditions will be a crucial aspect for evaluating the maximal swimming speed accessible. Total drag can moreover be directly measured by analyzing deceleration phases [38] and compared to our model results. Reporting leg stroke occurrence seems also necessary to disentangle the role of propulsion and thrust on the insect's speed. Tracking experiments could be further coupled with measurements of the energy consumption and gas exchanges to assess the metabolic cost associated [52]. Comparative and more comprehensible study of the ecological niches and lifestyles of the different gyrinids species is also required to further evaluate the role of size and air-water interface locomotion in gyrinids evolution. Thus, organismal biologists and ecologists also have plenty of opportunities for collaborative research.

Here we showed the importance of size and shape in the resistance to semi-immersive swimming. Our model will help pave the way for studies on the role of body design for dealing with drags and thereby aiding in the potential discovery of structures adapted for reducing drag. There is a need to characterize the shapes and body-forms that are representative of the diversity of gyrinids and could in turn be related to resistance management. Complementary to this is the need to develop tools for modeling and assessing the role of body form on the resistance forces experienced by such organisms. The mathematical description of the wave resistance used here can only take into account objects symmetrical about their center. The case of elongate, asymmetrical or arbitrary body forms cannot be described within this framework. Improved tools for modeling these diverse forms should be possible with commonly accessible computational power. For example, finite element simulations of 3D interfacial systems have very high numerical cost and thus are, at most, suitable to assess phenomenological models, but not for the analysis of various body shapes.

Our work also indicated the need for further bio-mechanical description of the rowing mechanism used by whirligig beetles, beyond the Marden and Allen scaling. Measurements 
of muscle mass will be paramount for characterizing the thrust force in more whirligig beetle species, including those of different body sizes [21,53]. Unsteady and non-linear movements may be the norm rather than the exception in the whirligig beetle locomotion as the speed is known to vary within the swimming cycles, trajectories are typically curved and the swimming speed can be multi-modal [22]. Gyrinus substriatus is known to accelerate at more than $4 \mathrm{~m} / \mathrm{s}^{2}$ which is comparable to gravity [22]. Additionally, for swimmers of a size close to that of the gravito-capillary length, transient effect are likely non-negligible [38]. Thus, there is a critical need for further improvements to the model presented here in order to be able to compute the drag forces associated with unsteady and non-linear movements. Here too more empirical data would help to better quantify these aspects of whirligig beetles trajectories. Indeed, whirligig beetles and their unique adult life at the water-air interface affords numerous opportunities for multidisciplinary research between physicists and biologists.

Supplementary Materials: The following are available online at https:/ /www.mdpi.com/article/10 .3390 / fluids6070249/s1, Table S1: Gyrinid size data.

Author Contributions: Conceptualization, L.J. and J.C.; Formal analysis, L.J., T.S. and M.P.; Investigation, L.J., G.T.G., T.S. and M.P.; Supervision, J.C.; Writing—original draft, L.J. and G.T.G.; Writing - review \& editing, L.J., G.T.G., T.S., M.P. and J.C. All authors have read and agreed to the published version of the manuscript.

Funding: This work formed part of the doctoral dissertation of L.J. under the supervision of J.C. We thank the ENS Lyon for supporting L.J. with a doctorate fellowship.

Institutional Review Board Statement: Not applicable.

Informed Consent Statement: Not applicable.

Data Availability Statement: Gyrinid size data used in this study are provided as supplementary materials.

Acknowledgments: We acknowledge Elie Raphaël for insightful discussions.

Conflicts of Interest: The authors declare no conflict of interest.

\section{References}

1. Zhang, Z.Q. Animal Biodiversity: An Outline of Higher-Level Classification and Survey of Taxonomic Richness; Magnolia Press: Waco, TX, USA, 2011.

2. Blagodatski, A.; Kryuchkov, M.; Sergeev, A.; Klimov, A.A.; Shcherbakov, M.R.; Enin, G.A.; Katanaev, V.L. Under-and over-water halves of Gyrinidae beetle eyes harbor different corneal nanocoatings providing adaptation to the water and air environments. Sci. Rep. 2014, 4, 1-6. [CrossRef]

3. Kolmes, S.A. Ecological and sensory aspects of prey capture by the whirligig beetle Dineutes discolor (Coleoptera: Gyrinidae). J. N. Y. Entomol. Soc. 1983, 91, 405-412.

4. Voise, J.; Casas, J. Echolocation in whirligig beetles using surface waves: An unsubstantiated conjecture. In Studying Vibrational Communication; Springer: Berlin/Heidelberg, Germany, 2014; pp. 303-317.

5. Nachtigall, W. Funktionelle Morphologie, Kinematik und Hydromechanik des Ruderapparates von Gyrinus. Z. Vgl. Physiol. 1961, 45, 193-226. [CrossRef]

6. Xu, Z.; Lenaghan, S.C.; Reese, B.E.; Jia, X.; Zhang, M. Experimental studies and dynamics modeling analysis of the swimming and diving of whirligig beetles (Coleoptera: Gyrinidae). PLoS Comput. Biol. 2012, 8, e1002792. [CrossRef] [PubMed]

7. Yuan, J.; Cho, S.K. Bio-inspired micro/mini propulsion at air-water interface: A review. J. Mech. Sci. Technol. 2012, 26, 3761-3768. [CrossRef]

8. Tian, L.; Li, Z.; Jin, E.; Ke, Q.; Dong, S.; Ma, Y. Improved flow performance of a centrifugal compressor based on pit formation on the notum of the whirligig beetle (Gyrinidae Latreille). Adv. Mech. Eng. 2015, 7, 1687814015591736. [CrossRef]

9. Jia, X.; Chen, Z.; Riedel, A.; Si, T.; Hamel, W.R.; Zhang, M. Energy-efficient surface propulsion inspired by whirligig beetles. IEEE Trans. Robot. 2015, 31, 1432-1443. [CrossRef]

10. Tucker, V.A. Wave-making by whirligig beetles (Gyrinidae). Science 1969, 166, 897-899. [CrossRef] [PubMed]

11. Härlin, C.; Henrikson, B.I.; Stenson, J.A.; Svensson, J.E. Species-specific predation on gyrinid beetles by the backswimmer, Notonecta glauca. Int. Ver. Theor. Angew. Limnol. Verhandlungen 2005, 29, 717-721. [CrossRef]

12. Romey, W.L.; Galbraith, E. Optimal group positioning after a predator attack: The influence of speed, sex, and satiation within mobile whirligig swarms. Behav. Ecol. 2008, 19, 338-343. [CrossRef] 
13. Vulinec, K.; Miller, M. Aggregation and predator avoidance in whirligig beetles (Coleoptera: Gyrinidae). J. N. Y. Entomol. Soc. 1989, 97, 438-447.

14. Romey, W.L. Position preferences within groups: Do whirligigs select positions which balance feeding opportunities with predator avoidance? Behav. Ecol. Sociobiol. 1995, 37, 195-200. [CrossRef]

15. Romey, W.L.; Wallace, A.C. Sex and the selfish herd: Sexual segregation within nonmating whirligig groups. Behav. Ecol. 2007, 18, 910-915. [CrossRef]

16. Romey, W.L.; Smith, A.L.; Buhl, J. Flash expansion and the repulsive herd. Anim. Behav. 2015, 110, 171-178. [CrossRef]

17. Larsén, O. On the Morphology and Function of the Locomotor Organs of the Gyrinidae and Other Coleoptera; Entomologiska Sällskapet i Lund: Lund, Sweden, 1966.

18. Nachtigall, W. Locomotion: Mechanics and hydrodynamics of swimming in aquatic insects. In The Physiology of Insecta; Elsevier: Amsterdam, The Netherlands, 1974; pp. 381-432.

19. Blake, R. Hydrodynamics of swimming in the water boatman, Cenocorixa bifida. Can. J. Zool. 1986, 64, 1606-1613. [CrossRef]

20. Whittlesey, R.W. Wake-based unsteady modeling of the aquatic beetle Dytiscus marginalis. J. Theor. Biol. 2011, 291, 14-21. [CrossRef]

21. Liu, S.P.; Wipfler, B.; Beutel, R.G. The unique locomotor apparatus of whirligig beetles of the tribe Orectochilini (Gyrinidae, Coleoptera). J. Zool. Syst. Evol. Res. 2018, 56, 196-208. [CrossRef]

22. Voise, J.; Casas, J. The management of fluid and wave resistances by whirligig beetles. J. R. Soc. Interface 2010, 7, 343-352 [CrossRef]

23. Fish, F.E.; Nicastro, A.J. Aquatic turning performance by the whirligig beetle: Constraints on maneuverability by a rigid biological system. J. Exp. Biol. 2003, 206, 1649-1656. [CrossRef] [PubMed]

24. Devereux, H.L.; Twomey, C.R.; Turner, M.S.; Thutupalli, S. Whirligig beetles as corralled active Brownian particles. J. R. Soc. Interface 2021, 18, 20210114. [CrossRef]

25. Steinmann, T.; Cribellier, A.; Casas, J. Singularity of the water strider propulsion mechanisms. J. Fluid Mech. 2021, 915, A118. [CrossRef]

26. Steinmann, T.; Arutkin, M.; Cochard, P.; Raphaël, E.; Casas, J.; Benzaquen, M. Unsteady wave pattern generation by water striders. J. Fluid Mech. 2018, 848, 370-387. [CrossRef]

27. Gao, P.; Feng, J.J. A numerical investigation of the propulsion of water walkers. J. Fluid Mech. 2011, 668, 363. [CrossRef]

28. Bush, J.W.; Hu, D.L. Walking on water: Biolocomotion at the interface. Annu. Rev. Fluid Mech. 2006, 38, 339-369. [CrossRef]

29. Miller, K.B.; Bergsten, J. Phylogeny and classification of whirligig beetles (Coleoptera: Gyrinidae): Relaxed-clock model outperforms parsimony and time-free Bayesian analyses. Syst. Entomol. 2012, 37, 706-746. [CrossRef]

30. Lighthill, M.J.; Lighthill, J. Waves in Fluids; Cambridge University Press: Cambridge, UK, 2001.

31. Moisy, F.; Rabaud, M. Mach-like capillary-gravity wakes. Phys. Rev. E 2014, 90, 023009. [CrossRef]

32. Raphaël, E.; De Gennes, P.G. Capillary gravity waves caused by a moving disturbance: Wave resistance. Phys. Rev. E 1996, 53, 3448. [CrossRef]

33. Benzaquen, M.; Raphael, E. Capillary-gravity waves on depth-dependent currents: Consequences for the wave resistance. EPL Europhys. Lett. 2012, 97, 14007. [CrossRef]

34. Chevy, F.; Raphaël, E. Capillary gravity waves: A "fixed-depth" analysis. EPL Europhys. Lett. 2003, 61, 796. [CrossRef]

35. Chepelianskii, A.; Chevy, F.; Raphael, E. Capillary-gravity waves generated by a slow moving object. Phys. Rev. Lett. 2008, 100, 074504. [CrossRef]

36. Closa, F.; Chepelianskii, A.; Raphael, E. Capillary-gravity waves generated by a sudden object motion. Phys. Fluids 2010, 22, 052107. [CrossRef]

37. Benzaquen, M.; Chevy, F.; Raphaël, É. Wave resistance for capillary gravity waves: Finite-size effects. EPL Europhys. Lett. 2011, 96, 34003. [CrossRef]

38. Le Merrer, M.; Clanet, C.; Quéré, D.; Raphaël, É.; Chevy, F. Wave drag on floating bodies. Proc. Natl. Acad. Sci. USA 2011, 108, 15064-15068. [CrossRef]

39. Burghelea, T.; Steinberg, V. Wave drag due to generation of capillary-gravity surface waves. Phys. Rev. E 2002, 66, 051204. [CrossRef]

40. Schlichting, H.; Gersten, K. Boundary-Layer Theory; Springer: Berlin/Heidelberg, Germany, 2016.

41. Pucci, G.; Ho, I.; Harris, D.M. Friction on water sliders. Sci. Rep. 2019, 9, 1-7.

42. Gazzola, M.; Argentina, M.; Mahadevan, L. Scaling macroscopic aquatic locomotion. Nat. Phys. 2014, 10, 758-761. [CrossRef]

43. Marden, J.H.; Allen, L.R. Molecules, muscles, and machines: Universal performance characteristics of motors. Proc. Natl. Acad. Sci. USA 2002, 99, 4161-4166. [CrossRef] [PubMed]

44. Marden, J.H. Scaling of maximum net force output by motors used for locomotion. J. Exp. Biol. 2005, 208, 1653-1664. [CrossRef] [PubMed]

45. Polilov, A.A.; Makarova, A.A. The scaling and allometry of organ size associated with miniaturization in insects: A case study for Coleoptera and Hymenoptera. Sci. Rep. 2017, 7, 1-7.

46. Gustafson, G.T.; Prokin, A.A.; Bukontaite, R.; Bergsten, J.; Miller, K.B. Tip-dated phylogeny of whirligig beetles reveals ancient lineage surviving on Madagascar. Sci. Rep. 2017, 7, 1-9. [CrossRef]

47. Nel, A. Les Gyrinidae fossiles de France (Coleoptera). Ann. Soc. Entomol. Fr. 1989, 25, 321-330. 
48. Liang, Z.; Qi, Z.; Chen, J.; Jia, F. Cretodineutus rotundus gen. et sp. nov., the oldest adult whirligig beetle from the Upper Cretaceous of Myanmar (Coleoptera, Gyrinidae, Gyrininae). Cretac. Res. 2020, 106, 104251. [CrossRef]

49. Beutel, R.G.; Wang, B.; Tan, J.J.; Ge, S.Q.; Ren, D.; Yang, X.K. On the phylogeny and evolution of Mesozoic and extant lineages of Adephaga (Coleoptera, Insecta). Cladistics 2013, 29, 147-165. [CrossRef]

50. Zhao, X.; Zhao, X.; Jarzembowski, E.A.; Chen, L.; Wang, B. First record of adult Coptoclava longipoda Ping (Coleoptera: Coptoclavidae) from the Lower Cretaceous of Laiyang, China. Cretac. Res. 2018, 92, 205-209. [CrossRef]

51. Wilkinson, S.; Rundle, S.; Brewin, P.; Ormerod, S. A study of the whirligig beetle Dineutus indicus (Aube) (Gyrinidae) in a Nepalese hillstream. Entomologist 1995, 114, 131-137.

52. Lipp, A.; Wolf, H.; Lehmann, F.O. Walking on inclines: Energetics of locomotion in the ant Camponotus. J. Exp. Biol. 2005, 208, 707-719. [CrossRef]

53. Beutel, R.G.; Yan, E.; Yavorskaya, M.; Büsse, S.; Gorb, S.N.; Wipfler, B. On the thoracic anatomy of the Madagascan Heterogyrus milloti and the phylogeny of Gyrinidae (Coleoptera). Syst. Entomol. 2019, 44, 336-360. [CrossRef] 